\title{
CHARACTERISTIC OF FACTORS THAT INFLUENCE THE FORMATION OF THE HUMANISTIC PEDAGOGICAL POSITION OF FUTURE SPEECH THERAPISTS
}

\author{
Nataliya Fedorova \\ Ponymanskaya T. I. Department of Pedagogy and Psychology (Preschool and Correctional) \\ Rivne State Humanities University \\ 12 Stepana Bandery str., Rivne, Ukraine, 33028 \\ E-mail: nataliya76fedorova@gmail.com
}

\begin{abstract}
The article analyzes factors that influence the formation of the humanistic pedagogical position of future speech therapists, understood as a personal phenomenon that integrates values and senses of pedagogical activity of the humanistic directionality. The research characterizes internal and external factors of the formation of the humanistic pedagogical position of future speech therapists. Important internal factors of the formation of the humanistic pedagogical position of future specialists are:

- self-consciousness - adequate self-estimation, axiological self-attitude, reflection as an ability to understand own peculiarities, report to yourself about other's understanding of them, to form own behavior taking into account probable reactions of important people;

- personal experience - understood as cognition results, accumulated by studied people, based on their sensual practical comprehension at the educational process, in the educational environment and in the wide life context.

External factors are educational process and environment, external as to the subjective humanistic pedagogical position of a future specialist:

- attitude to the problem of the formation of the aforementioned position in future speech therapists by teachers of basic educational institutions;

- content filling of curriculums, guiding teaching general and special disciplines for this category of specialists.

The professional activity of a speech therapist is a complex of interconnected processes, depending on numerous and diverse factors - internal and external ones.

Internal and external factors are analyzed, strong and weak sides of the organization of the educational process and environment under traditional learning conditions that brake the process of formation of the humanistic pedagogical position of future speech therapists are determined, the analysis of an influence of contents of learning programs of the disciplines "Special education. Speech therapy" that determine a strategy and tactics of their teaching was made.

Keywords: humanistic pedagogical position of future speech therapist, formation factors of the humanistic pedagogical position.
\end{abstract}

DOI: 10.21303/2504-5571.2019.001010

\section{Introduction}

Humanism and tolerance relative to persons with special needs determines a consciousness level of a nation and a development degree of a society. The historical review of the humanistic pedagogy development and analysis of the modern education condition reasonably prove that the idea of humanism, laid in the base of most famous progressive pedagogical conceptions, gains most topicality in crucial periods of the social development, when a need of a certain society in spiritual unity of people is strictly traced. Just that is why today there takes place an orientation of the Ukrainian society on democratic principles, humanization of the learning-upbringing process, introduction of the inclusive educational environment. Humanization of an attitude of the modern Ukrainian society to persons with development problems, at first manifested in integration ideas, then - in the state policy of inclusion in education and all other spheres of social life, has introduced essential changes in the professional activity of teachers in general and, in particular, teachers in the sphere of special education: defectologists, teachers-speech therapists. It is just natural, that in this connection the state sets qualitatively new requirements to specialists of the system of special education.

Article 19 of the Law of Ukraine "On education" "Education of persons with special needs" provides creation of conditions for giving rights and possibilities to persons with special education- 
al needs for getting education at all levels, taking into account their individual needs, possibilities, abilities and interests, and also provision of training specialists for working with persons with special educational needs at all educational levels by the state [1].

Leading modern Ukrainian scientists in the sphere of special education elaborated a project of the standard of higher education in Ukraine for specialty 016 "Special education" [2] that provides also the formation of the humanistic pedagogical position of future specialists.

The studies testify that the professional-pedagogical training of future speech therapists in higher educational institutions is directed on the formation of system knowledge and pedagogical skills in them, readiness for innovative activity, on the continuous enrichment of professional possibilities and improvement of personal qualities, the formation of the active, humanistic pedagogical position of a speech therapist [3, 4].

Aim of the article. The aim of this article is in determining factors, influencing the formation of the humanistic pedagogical position of future speech therapists under usual conditions of their training.

\section{Materials and methods}

The humanistic pedagogical position (HPP) of a future speech therapist is understood as a personal phenomenon that integrates values and senses of the pedagogical activity of the humanistic directionality. The content of HPP is value-notional, its structure - an integrated characteristics of an attitude of a future specialist to his/her professional activity, clients and him/herself. Important sides of HPP of a future speech therapist are the worldview one (understanding of an important role of the chosen profession, conviction in the own correct choice, formation of adequate images of the socio-professional space and the own Me); moral ethical (orientation on ethical norms, formation of basic moral values); behavioral (presence of the competent, expedient, constructive behavior and pedagogical actions) $[5,6]$.

The process of formation of the humanistic pedagogical position of future speech therapists is influenced by many factors. As it is noted by leading specialists, the readiness to the future professional activity is, in first turn, determined by the system of students' attitudes. An attitude of future speech therapists to themselves, to the chosen profession and preschool children mainly conditions a measure of their personal and professional competence [7].

The diversity of connections of the student youth in the professional activity is determined by the ability of modern specialists to regulate their behavior, to manifest intellectual, emotional-volitional, moral-spiritual qualities and also by a content, complication, novelty, social importance of this type of activity. The system of personal- activity relations is very dynamic and provides both the development of a person itself and ways of the professional activity realization. This system reveals contradictions between personal constructions, external activity and social factors that act as requirements and development stimuli of features and qualities, adequate to concrete forms of behavior. At the same time the student's inclusion to the professional activity as an active subject, orientation on realization of aims and tasks condition his/her striving for adapting its content and ways of realization of own possibilities [8-12].

In our study we were guided by specialists' principles, according to which, reflection of relations in the spheres "Me", "Me and children", "Me and profession" by a future speech therapist makes the formation of the active pedagogical position possible, is a necessary condition of self-understanding and self-attitude. The presence of the professional position allows to talk about the brightly expressed directionality of a future speech therapist, to characterize it as an integral or conflict, strong or weak. The professional position can testify to the beginning of the professional deformation of a person, discordance of imaginations and conditions of the professional self-determination of the student youth. A level of its behavior and activity is to the great extent determined by the development of Me-image that is a main factor of personal activity.

So, the formation of self-consciousness in future speech therapists -- adequate self-estimation, axiological self-attitude, reflection as an ability to understand own peculiarities, report to yourself about other's understanding of them, to form own behavior, taking into account probable 
reactions of important people, are important internal factors of the formation of the humanistic pedagogical position of future specialists [13-16].

As it is established in the ascertaining experiment of our study, the essential number of studied persons is characterized with an inadequate self-estimation: too high (25,6\%) and too low $(19,2 \%)$. Future speech therapists of the last category treat themselves extremely critically, articulate judgments about themselves carefully. Near one third of future speech therapists differs by an unstable self-estimation, its dependence on judgments of authorities. Only one fifth of the participants of the experiment are characterized with an adequate self-estimation, axiological self-attitude, ability to pedagogical reflection. Not occasionally, it was more difficult for future speech therapists to determine an attitude to themselves than to the profession and future pupils.

\section{Result}

The polling of future speech therapists at the stage of ascertaining testified that their important part (42,6\%) are not satisfied with themselves, social status of parents, place, occupied in society. They note that they cannot occupy a correspondent place in society because of insufficient realization of their mothers and fathers: are not able to defend themselves, to advocate own convictions, feel uncertainty among unknown people and so on.

According to the research data, 36,2\% of students want to be materially independent from parents, search different ways of self-realization for that. As a result, they find most diverse ways of earning money: raised grant, work as governesses, at super-markets and so on. They stress: "It gives freedom of actions, provides a possibility to realize oneself in different spheres". Material independence is for them a base for the development of own importance, satisfaction of a need "to be not worse than others". They articulated an idea about the expedience of introducing the method of stimulating students' activity at higher educational institutions, creating conditions, at which bad manners, lack of education, violation of the discipline and public order become unprofitable.

Answers for questions of a form and conversation testified that motivations of self-upbringing are inherent only to $16,0 \%$ of respondents. For some of them the professional upbringing started after acquaintance with the chosen profession, requirements, set by it. This category of future speech therapists noted: understanding of a necessity to change the status from the position" "I'm a student, teach me and bring me up" to the position "I'm a future specialist. I train myself for the important profession"; must master the experience of independent work for enriching knowledge, skills for own self-improvement.

A crucial moment for one fifth of respondents became the independent activity at the pedagogical practice. Students noted that communication with children with special needs stimulates the striving for improving oneself as a person and future specialist, favors acquisition of the experience in making own decisions, responsible choices, solving conflict situations. Future speech therapists underlined that put the questions to themselves: "What a teacher I must to become?", "What can I do for attracting future pupils?". So, the ability for pedagogical reflection successively formed in them.

It was realized, that only $9,6 \%$ of the polled students accented attention at questioning on the importance of developing own individuality, stressed the importance of striving for independence from others, desire to produce original ideas and solutions, ability to keep own uniqueness, to defend the feeling of own dignity, to advocate own position, to prove its legality under external pressure. Awareness of the importance of the individual development by future speech speech therapists, taking into account individual life stories of future pupils in the educational process, realization of differentiated and individual approaches to learning and upbringing - is an important condition of the future professional activity optimization.

Taking into account the fact that the development of personal self-consciousness is important for determining the social status of a future speech therapist by him/herself, expressions of $6,4 \%$ of respondent about the motivation of social prestige are worth attention. These students emphasized a necessity in providing the just attitude of teachers in the learning and upbringing processes, noted that social unevenness, observed in their academic groups, negatively influences the self-estimation, decrease strivings, provoke isolation, lack of desire to communication or, on the contrary, aggressive, conflict behavior. 
A health status of a future speech therapist is reflected on his/her well-being, ability to self-realize and to self-improve. At the same time only 3,2 \% of respondents noted that it is necessary to pay attention to own health, to search for reserves of its keeping and strengthening (sleep for a proper time, observe personal hygiene, eat rationally, control own body mass, refuse smoking, alcohol abuse, undergo prophylactic medical examinations, be treated, if ill).

The polling testified: significant number of students $(45,8 \%)$ underlined the importance for the successful professional activity of not only physical, but also moral-spiritual health. It gives reasons to state that students understand: internal conflicts, contradictions, misunderstandings, negative emotional conditions don't favor the harmony of the physical and spiritual condition of the organism, brake the effectiveness of the humanistic pedagogical position formation.

Internal factors that influence a degree of the humanistic pedagogical position formation in a future speech therapist as a system of attitudes to him/herself, to the profession and preschool children include personal experience. It is understood as cognition results, accumulated by studied people, based on their sensual practical comprehension at the educational process, in the educational environment and in the wide life context. Personal experience is an important resource of information about both external objective world and own spiritual-soulful life for a future specialist.

Our study is based on the idea that students' achievements as ones of active subjects of the educational process are fixed in their knowledge, abilities and skills, habits, attitudes. The latter form their personal experience that qualitatively and quantitatively changes during life (personal and professional) as a dynamic construction. Taking into account the fact that the personal experience is enriched, complicated, diversified with age and under the influence of learning and upbringing at a higher educational institution, it is reflected on characteristics of the humanistic pedagogical position of students of different years, especially beginners and graduates.

For determining the dynamics of changes in the humanistic pedagogical position of future speech therapists, the students of I, II, III and IV years of the specialty "Special education. Speech therapy" were quantitatively distributed by formation levels of this position in them. The comparative characteristic is given in Table $\mathbf{1 .}$

Table 1

Development dynamics of the humanistic pedagogical position of I-IV year students (in \%)

\begin{tabular}{ccccc}
\hline Position formation levels & \multicolumn{3}{c}{ Years } \\
\cline { 2 - 5 } & $\mathbf{4}$ & $\mathbf{3}$ & $\mathbf{2}$ & $\mathbf{1}$ \\
\hline High (constructive-creative) & 19,2 & 18,2 & 16,0 & 12,8 \\
Optimal (constructive-reproductive) & 28.8 & 26,4 & 25,6 & 22,4 \\
Middle (ambivalent, contradictory) & 33,0 & 39,4 & 39,4 & 42,4 \\
Low (destructive-reproductive) & 14,8 & 16,0 & 19,0 & 22,4
\end{tabular}

The qualitative analysis of the quantitative data, presented in table 1 , allows to make the following generalizations.

In general, it is proved that year by year the parameters of the humanistic pedagogical position formation in future speech therapists improve. That is the experience, acquired with time, is testified by the width and depth of knowledge, more determination and stability of the emotional-axiological attitude and gained skills of the axiological attitude to others and themselves. If at 1 year 35,2\% were related to the high and optimal levels of the humanistic pedagogical position formation, at the graduate one $-48 \%$. It has been established, that the number of students with the low indices of this position decreased by $7,4 \%$. So, there are reasons to state that the educational process organization at base higher educational institutions at the traditional system of training speech therapists is positively reflected on the experience of future specialists, enriches their knowledge, widens understandings, brings minimal necessary behavior habits up. Their further growth becomes possible at introducing the author model of the humanistic pedagogical position formation into the pedagogical practice.

The analysis of future speech therapists' answers testified that they have hope enough that essential changes in their intellectual and personal development will take place during study- 
ing, they make self-development programs for a concrete studying period for it. Most of them $(77,8 \%)$ at that indicate concrete ways, by which these changes will be realized, foreseeing probable complications, omissions. Thus, according to first-year students, these changes will take place under the teachers' influence; graduates, on the contrary, stress the influence of self-education, information means. They ascertain that "self-confidence appeared", "became to understand own abilities", "self-estimation increased", "understand well future professional activity peculiarities".

It has been established, that $36,2 \%$ of interviewed students note that motivation, understanding of the necessity to self-determine, creatively self-express, self-improve increased ("interest to children with special needs grew", "desire to read and to analyze professional literature increased", "active search for specialist for sharing experience increased", "desire to search for alternative forms of improving the own profession comprehensively - trainings, online conference and so on appeared").

So, we can say that the essential number of students had understood the importance of the careful work for themselves, which resulted in the content transformation of their values: the behavior became more independent; punctuality in making tasks at the pedagogical practice increased; tolerance in the attitude to another idea rose; the readiness to give help was manifested, worldview convictions grew better.

At the same time, $25,6 \%$ of respondents critically noted that during studying at the higher educational institution an inclination to "aggression", "indifference", "sarcasm", "cruelty" and so on appeared. It may be explained by the essential learning load, life intensity, lack of time for attractions, low material status of the family and so on. At the forming experiment it will be necessary to pay attention to this category of studied.

It is expedient to note: more than a third of the interviewed graduates indicated negative changes in the development of understanding of themselves as future speech therapists: if at the first years more unsatisfied with others (teachers, classmates, friends) were revealed, graduates stressed, first of all, own mistakes ("disappointed in the profession choice", "lost hope to realize myself in the chosen profession", "not sure in own necessity as a future specialist", "doubt own forces and abilities", "reality doesn't correspond to expectations", "forgot something than had known before the university", "no connection between theory and pedagogical practice", "desire to be a teacher is lost" and so on.

As it is testified by the polling, near one fifth of the studied graduates fixed complications in the learning activity, unjust attitude of teachers to them, emotional exhaustion ("feel tired very fast", "became irritable", "became exhausted fast", "became indifferent to all", "lost interest to studying" and so on). It is explained, on the one hand, by the real complication of living realities in our state, on the other one - formation of the ability to estimate oneself more critically, differentiated as a person and future specialist. The revealed data are taken into account in determining a methodology for organizing the specially directed work with the student youth.

It was told above about the development peculiarities of future speech therapists' self-consciousness and experience (knowledge, skills, abilities, axiological orientations) during four years of studying at a higher educational institution of the pedagogical profile, related to internal factors of the influence on the humanistic pedagogical position. The internal factors determine a resource, personal and professional potential of the student youth, its weak and strong sides.

The professional activity of a speech therapist is a complex of interconnected processes, dependent on numerous and diverse factors, internal and external. These factors have the multidirectional influence on the student youth's life activity: negative and positive. A negative influence of ones can eliminate a positive one of others.

External factors are educational process and environment, external as to the subjective humanistic pedagogical position of a future specialist. They can optimize the process of its formation and also to brake, to limit the positive influence on it, result in loss of the working ability by future speech therapists.

We'll stop below on a characteristic of such external factors as an attitude to the problem of formation of the aforesaid position of speech therapists by teachers of base educational institutions and content filling of curriculums, guiding teaching general and special disciplines for this category of specialists. 
An attitude of teachers to the studied phenomenon and its formation conditions is studied by polling of the special directionality. Table 2 presents the generalized polling data of 30 teachers of the special disciplines.

Table 2

Quantitative distribution of answer variants of teachers to the asked questions

\begin{tabular}{|c|c|c|}
\hline Question & Answer variant & Number of studied (in \%) \\
\hline & $\begin{array}{l}\text { Humanistic, respectful attitude to children with special } \\
\text { needs }\end{array}$ & 58,6 \\
\hline \multirow{4}{*}{$\begin{array}{l}\text { 1. Determination criterion of the } \\
\text { formation level of the humanistic } \\
\text { pedagogical position of students }\end{array}$} & Active type of the student's life activity & 25,6 \\
\hline & Culture level, good manners of a future specialist & 19,2 \\
\hline & Correspondence between actions and verbal expressions & 6,6 \\
\hline & Formed only in a certain part & 39,4 \\
\hline \multirow{3}{*}{$\begin{array}{l}\text { 2. Is the humanistic pedagogical } \\
\text { position formed in all students? }\end{array}$} & In all, but is manifested occasionally & 28,6 \\
\hline & If formed by intuition in all & 22,4 \\
\hline & It not formed in predominant majority & 9,6 \\
\hline \multirow[t]{3}{*}{$\begin{array}{c}\text { 3. Is the humanistic pedagogical pom } \\
\text { sition important for a future speech } \\
\text { therapist? }\end{array}$} & Yeas, undoubtedly important & 100,0 \\
\hline & Benevolence, tolerance & 36,2 \\
\hline & Ability to dialogue, communication & 19,2 \\
\hline \multirow{5}{*}{$\begin{array}{c}\text { 4. Skills of the humanistic } \\
\text { pedagogical position, mostly used } \\
\text { by students }\end{array}$} & Respect to others & 16,0 \\
\hline & Striving for giving help & 12,6 \\
\hline & Patience, endurance & 9,6 \\
\hline & Self-cognition & 6,4 \\
\hline & Pedagogical practice & 33,0 \\
\hline \multirow{5}{*}{$\begin{array}{l}\text { 5. In which activity types the humant } \\
\text { istic pedagogical position of students } \\
\text { is realized mostly? }\end{array}$} & Volunteer activity & 22,4 \\
\hline & Voluntary actions, charity auctions & 19,2 \\
\hline & Laboratory activities & 16,0 \\
\hline & Interactive learning & 12,6 \\
\hline & Individual activities with speech patients & 6,8 \\
\hline \multirow{3}{*}{$\begin{array}{l}\text { 6. Frequency of using the term } \\
\text { "humanistic pedagogical position" } \\
\text { in communication }\end{array}$} & From time to time & 52,2 \\
\hline & Seldom & 39,4 \\
\hline & Often & 8,4 \\
\hline \multirow{3}{*}{$\begin{array}{c}\text { 7. Do you have modern methods of } \\
\text { forming the humanistic pedagogical } \\
\text { position? }\end{array}$} & Don't have & 49,0 \\
\hline & Partially have & 36,2 \\
\hline & Have & 14,8 \\
\hline \multirow{3}{*}{$\begin{array}{l}\text { 8. Are necessary methodical } \\
\text { materials enough? }\end{array}$} & Materials are practically absent & 55,4 \\
\hline & Not enough & 36,2 \\
\hline & Enough & 8,4 \\
\hline \multirow{3}{*}{$\begin{array}{l}\text { 9. Are co-workers interested in the } \\
\text { problem of the humanistic } \\
\text { pedagogical position formation? }\end{array}$} & Yes & 52,2 \\
\hline & Are interested to a certain extent & 41,4 \\
\hline & Answer is absent & 6,4 \\
\hline \multirow{2}{*}{$\begin{array}{l}\text { 10. Do you use research data of } \\
\text { specialists in this problem? }\end{array}$} & Yes & 55,4 \\
\hline & Answer is absent & 44,6 \\
\hline
\end{tabular}


As it is testified by the analysis of the teachers' answers, given in Table 2, respondents at determining assessment criteria of the humanistic pedagogical position accented attention on the humanistic attitude to children with special needs, tolerance to surrounding people, active life activity of the student youth, its culture, good manners, correspondence between words and real actions. There is an obvious conclusion: in general, a vector of determination of a leading category by the teachers is characterized correctly, but without enough system, complex, excessively concretely. Such characteristics of the humanistic pedagogical position as the development of speech therapists' worldview, convictions, axiological orientations, ability to acknowledge the other's right for realization of own abilities and satisfaction of own needs was left beyond proper teachers' attention. It actualizes a necessity to use jottings of a correspondent content, addressed to teachers at the formation stage.

We were interested in the teachers' assessment of the proper formation level of the humanistic pedagogical position in all students. It became obvious, that none teacher gave the unambiguously positive answer. Compromise variants of answers prevailed: "is manifested occasionally" (near one third), "forms by intuition" (near one fourth), "is formed only in a certain part" $40 \%$ ), "not formed in the majority (near one tenth). It may be said, that the absence of distinct indexes testifies the approximate character of teachers' ideas about the real distribution of students by formation levels of the humanistic pedagogical position in them.

All interviewed teachers without exclusion agreed in determining the importance of the humanistic pedagogical position for the speech therapist profession. Among skill, used mostly by students, testifying its formation, there were named: benevolence, humanism, tolerance (more than one third), communicative skills, ability to dialogue, conversation (more than one fifth), respect to other (16\%), readiness to give help (more than one tenth), endurance, patience (near one tenth), ability to self-cognition (more than $6 \%$ ). It's worth noting, that separate teachers added to the list such manifestations of students' behavior that don't directly relate to the notion "pedagogical position" as high-culture address, readiness to give a place in transport, care for animals.

Teachers' answers about activity types, which manifest students' humanistic pedagogical position turned out interest and diverse. At the first place by the number of supporters is pedagogical practice (one third of interviewed), at the second - volunteer activity (more than fifth part), at the third place - voluntary actions and charity auctions (near a fifth part). One third of other respondents gave priority to laboratory activities, interactive learning forms and individual activities with speech patients.

Teachers' assessments of the frequency of using the notion "humanistic pedagogical position" in communication with future speech therapists are remarkable. It became obvious, that more than a half of interviewed uses it seldom, from time to time, at teaching special disciplines; almost $40 \%$ accepted that use it very seldom; only near one tenth positively estimated the use of the leading category in their pedagogical activity.

Estimating the method of the humanistic pedagogical position formation in students, teachers were very self-critical: almost a half of them inclined to the negative conclusion; more than one third accepted it satisfactory ("partially have"); only near $15 \%$ were optimists and estimated own methodological literacy in this direction positively.

It is anxious, that teachers' assessments of the presence of methodical and didactic materials on the problem of humanistic pedagogical position formation in future speech therapists are pessimistic. More than $55 \%$ indicated their absence, more than one third - their deficit, only near one tenth expressed the optimistic judgment as to this question.

Expressions of the interviewed teachers give grounds to make a conclusion that the overwhelming majority of their co-workers demonstrate interest to the problem of humanistic pedagogical position formation in the student youth: more than a half gave the positive answer, more than $40 \%$ - compromise («yes to a certain extent"). It must be noted, that $6 \%$ of interrogated avoided answering this question. It may be explained by both, insufficient information about it and lack of desire to express negative judgments about other.

Answers to the last question of the form about which specialists' works are used by the teachers in the humanistic pedagogical position formation of the student youth are interesting. The interrogation testified that more than $55 \%$ of the teachers confirmed that that use scientific contributions of such leading specialists as S. Amonashvili, I. Bekh, L. Vrochinska, O. Kosareva, 
N. Pakhomova, T. Ponimanska, V. Slastionin, V. Sukhomlinsky and other [17-23]. At the same time near $45 \%$ of respondents left this question without an answer. It must be accepted as an anxious fact that needs serious attention.

Thus, the polling allowed to determine strong and weak sides of the educational process and educational environment organization under traditional learning conditions that brake the process of humanistic pedagogical position formation in future speech therapists. Main defects must be considered as: insufficiently systemic, integral approach of teachers to this problem; domination of the orientation on moral-ethical and behavioral sides of the position, comparing with a worldview one; indistinctness of determination criteria of the content of the leading category; insufficient information level as to students' characteristics, own methodical and scientific equipment. All aforesaid aspects of the problem will be in the field of researcher's attention at the forming stage.

The following factor that needed our attention was the analysis of an influence of contents of learning programs of the disciplines "Special education. Speech therapy" that determine a strategy and tactics of their teaching.

Let's get several conclusions on its base.

The positive ones:

1. Proper attention to peculiarities of preschool children with special needs, in first turn, physiological ones.

2. Harmonious combination of lectures and practical activities in the content.

3. Allocation of an essential number of hours for the independent work of students.

4. Orientation on moral upbringing of a future specialist, development of his/her culture.

The following may be related to negative:

1. The accent is traditionally made on mastering knowledge by children with special needs and ordering their behavior and activity. The notions "person", "individuality" are used seldom, rather in the general context that is not correct, taking into account the introduction of the personally oriented educational model in the pedagogical practice.

2. It is desired to intensify attention to the problem of the development of the personal and professional competence of future speech therapists in programs, at that intensifying attention to the development of the adequate integral image of the world and life-giving Me-conception in them.

3. The base of the content of learning programs must be not only pedagogical and methodical development aspects of the students' readiness to the activity of speech therapist-defectologist, but also psychological and social ones.

4. The question of the formation of a worldview position, convictions, system of axiological attitude to oneself as to a person and specialist, to the activity of a speech therapist, to preschool children with special needs in the student youth needs deep attention.

5. Modernization of technologies of humanistic pedagogical position formation in future speech therapists is necessary.

6. Introduction of the individual approach in the pedagogical practice, taking into account abilities of students and future pupils must gain the special importance.

\section{Conclusions}

The article analyzes factors that influence the formation of the humanistic pedagogical position of future speech therapists. Internal factors are: self-consciousness (adequate self-estimation, axiological self-attitude, reflection) and Personal experience (cognition results, accumulated by studied people, based on their sensual practical comprehension at the educational process, in the educational environment and in the wide life context).

Important external factors are an attitude to the problem of formation of the aforesaid position in speech therapists by teachers of base educational institutions and content filling of curriculums, guiding teaching general and special disciplines for this category of specialists.

The internal and external factors of the formation of the humanistic pedagogical position of future speech therapists, characterized in the study, outline directions and ways of organizing the forming experiment, influence determining principles and pedagogical conditions that forms further prospects of our research. 


\section{References}

[1] Zakon Ukrainy Pro osvitu. Available at: https://kodeksy.com.ua/pro_osvitu/statja-19.htm

[2] Osvitno-profesiina prohrama z haluzi znan 01 Osvita, spetsialnosti 016 Spetsialna osvita. Available at: http://www.rshu.edu. ua/images/osvitni_programi/osv_prog_bak_016_spec_osvita_2017.pdf

[3] Bekh, I. D. (2002). Nova pedahohichna pozytsiya yak predmet naukovoho osmyslennia. Problemy profesiynoi pidhotovky vchytelia shkoly maibutnoho: zb. m-liv Vseukr. nauk.-prakt. konf., 1, 4-14.

[4] Ponimanska, T. I., Dychkivska, I. M., Vrochynska, L. I. et. al. (2012). Humanistychne vykhovannia ditei doshkilnoho viku v konteksti innovatsiynoi pedahohichnoi diyalnosti. Rivne: Volyn. oberehy, 206.

[5] Fedorova, N. V. (2018). Humanistychna pedahohichna pozytsiya maibutnikh lohopediv yak tsinnisno-smyslova osnova profesiynoi diyalnosti. Osvita osib z osoblyvymy potrebamy: vyklyky sohodennia: Zbirnyk materialiv Vseukrainskoi naukovo-praktychnoi konferentsiyi. Kyiv: Instytut spetsialnoi pedahohiky NAPN Ukrainy, 160-165.

[6] Fedorova, N. V. (2018). Komponenty, kryteriyi ta pokaznyky sformovanosti humanistychnoi pedahohichnoi pozytsiyi maibutnikh lohopediv. Naukovo-metodychnyi zhurnal "Lohopediya", 12, 111-119.

[7] Kolupaeva, A. (2014). Special education in Ukraine and modernization of the educational sector. Osoblyva dytyna: navchannia i vykhovannia, 3, 7-12. Available at: http://nbuv.gov.ua/UJRN/DLog_2014_3_3

[8] Myronova, S. P. (2007). Pidhotovka vchyteliv do korektsiynoi roboty v systemi osvity ditei z vadamy intelektu. KamianetsPodilskyi, 304.

[9] Pakhomova, N. (2014). Reflexive and evaluation activity in the context of the integration professional training of the future speech therapists. Liudynoznavchi studiyi, 29, 131-140.

[10] Pakhomova, N. H. (2011). Metodolohichni osnovy systemnosti profesiynoi pidhotovky. Visnyk Luhanskoho Natsionalnoho universytetu im. T. Shevchenka. Pedahohichni nauky, 23 (234), 268-273.

[11] Pakhomova, N. H. (2011). Systemnist yak metodolohichna osnova profesiynoi pidhotovky vchytelia-lohopeda. Naukovyi chasopys NPU imeni M. P. Drahomanova. Seriya 19: Korektsiina pedahohika ta spetsialna psykholohiya, 18, 191-195.

[12] Pakhomova, N. H., Spivaka, V. I.; Havrylov, O. V., Spivak, V. I. (Eds.) (2011). Kontseptualni osnovy systemnosti profesiynoi pidhotovky defektolohiv. Seriya: sotsialno-pedahohichna, XVII (1), 114-122.

[13] Pinchuk, Yu. V. (2005). Systema profesiynoi kompetentnosti vchytelia- lohopeda. Kyiv, 220.

[14] Ponimans'ka, T. I. (2013). Formation of humanistic individual-professional position during training of educators. Dukhovnist osobystosti: metodolohiya, teoriya i praktyka, 6, 143-150.

[15] Fedorova, N. V. (2018). Sutnist humanistychnoi pedahohichnoi pozytsiyi maibutnoho lohopeda. Innovatyka u vykhovanni, 7 (1), 285-294.

[16] Fedorova, N. V. (2018). Theoretical aspects of professional training of the speech therapist during university education. Naukovyi visnyk Kremenetskoi oblasnoi humanitarno-pedahohichnoi akademiyi im. Tarasa Shevchenka. Seriya: Pedahohika, 10, $104-114$.

[17] Fedorovych, L. O. (2012). Psykholohichni resursy zabezpechennia uspishnosti navchalnoi diyalnosti studentiv, maibutnikh lohopediv. Zbirnyk naukovykh prats Kamianets-Podilskoho natsionalnoho universytetu imeni Ivana Ohiienka, 20 (1), $421-428$.

[18] Fedorenko, S. (2014). Humanistic-cultural paradigm as a methodological basis for the shaping of liberal culture of students in the USA higher education. Pedahohichni nauky: teoriya, istoriya, innovatsiyni tekhnolohiyi, 4, 66-75. Available at: http:// nbuv.gov.ua/UJRN/pednauk_2014_4_9

[19] Sheremet, M. K. (2011). Pidhotovka korektsiynykh pedahohiv u vyshchykh navchalnykh zakladakh Ukrainy. Zbirnyk naukovykh prats Kamianets-Podilskoho natsionalnoho universytetu imeni Ivana Ohiienka. Seriya: Sotsialno-pedahohichna, 17 (1), 7-11.

[20] Kosarieva, G., Pavlyuk, T., Fedorova, N. (2019). Training of future speech therapists to work with children of preschool age with special needs on the basis of humanistic ideas of tolerance. Problem space of modern society: philosophical-communicative and pedagogical interpretations. Part II. Warsaw: BMT Erida Sp. z o.o, 357-372.

[21] Abrandt Dahlgren, M., Hammar Chiriac, E. (2009). Learning for professional life: Student teachers' and graduated teachers' views of learning, responsibility and collaboration. Teaching and Teacher Education, 25 (8), 991-999. doi: https://doi.org/ 10.1016/j.tate.2009.03.019

[22] Darling-Hammond, L. (2009). Teacher Education and the American Future. Journal of Teacher Education, 61 (1-2), $35-47$. doi: https://doi.org/10.1177/0022487109348024

[23] Assemgul, A., Moldazhanovaa, A., Amanovaa, A, Amanjol, A., Tashetova, A., Bissembaevab, K., Gulzhanar, K. (2016). Future Teacher-Psychologists' Professional Position as a Component of Professional Competence Formation. International Journal of Environmental \& Science Education, 11 (18), 12317-12325. 